\title{
The Opression of Female Workers in Industrial Sector from Gayatri Spivak Prespective
}

\author{
Lukitaningsih \\ Ph.D Student at Faculty of Social Science and Politics, Airlangga University \\ Lecturer at Social Science Faculty, State University of Medan, Indonesia
}

\begin{abstract}
This study examines the oppression of female workers from Gayatri Spivak perspective, especially on the silence of female workers due to the patriarchal culture and the gender imbalances, and understands the meaning of oppression experienced by female workers. This research was conducted in the industry of Medan City, with feminist ethnography method, focuses on subjects experience (views, behavioral expressions, actions) about the oppression object of female workers. In order to obtain the data and information about the meaning of oppression, there are 16 subjects were directly involved in experiencing the oppression and 5 informants who have knowledge about workers on the oppression experienced by female factory workers. The result of the study was the silence of female workers is due to patriarchal culture, puts the women dominated and subordinated within the scope of family and society, the patriarchal structure which places the men as the dominant in the family. The influence of the patriarchy is the division of work by sex in the industrial sector. Female workers experience oppression due to the gender inequality. The differences of men and women caused by patriarchy have produced the gender inequalities in the industrial sector in the form of subordination, violence, discrimination, stereotype, marginal double burden. The oppression is interpreted by female workers as a compulsion to play a role in helping the economy of the family and increasing the production output to the company. This study finds that socio-economic factors cause female workers experience oppression in the domestic and public sectors; there is a gap for female workers to negotiate with husbands, companies, supervisors, team leaders, in written, verbal and insurgent forms through body language. In Spivak's theory, the subaltern is experiencing oppression in the culture, religion and power. Meanwhile in this study it reveals the economic influence in the domestic and public sectors that causes the female workers to speak out.
\end{abstract}

Keywords: oppression, female worker, Gayatri Spivak; prespective

\section{INTRODUCTION}

In Indonesia the cases of oppressed female workers by the employers in industrial sector are much conducted as happened in Medan. Industrial companies exploited and repressed the female workers in the form of heavy workloads, long working hours, work that full of accident risk, no reproductive protection for female workers while working in factories, working for 7 hours in standing position. On the other hand female workers also experience marginalization and subordination actions by companies such as differentiating female workers' wages with male workers, Chinese ethnic female workers, unavailability of lactation rooms, violations of maternity rights, recruitment systems, dismissal after maternity leave to miscarriage at work, they also experience sexual harassment committed by the foreman, male workers. The existence of asymmetrical relationship which is committed by the company that the entrepreneur can do anything to the female workers, so that the choice is keep on working but obey the rules, or disobey the rules with the consequences of termination of employment. When the female workers take on rallies or strikes to keep on work and earn a living, the entrepreneur almost never comes to meet the male and female workers. At that time the entrepreneur shows his strength and knows that job opportunities are very limited, while the job seekers or labor are many. The phenomenon of female's struggle against industrial entrepreneurs on the arbitrary acts to female factory workers is an empirical portrait of the discourse of subaltern group struggle introduced by Spivak, or "silent" group.

The basic concept of subaltern according to Spivak (2010: 78) is seeing how the relationship of domination to the subordinate in some the society former colonial on the issue of gender differences and the pressure of the ruler in the life of women. In relation to this study the relationship between female and the rulers, or women labors and other laborers, there are certainly a number of people who are entrusted by employers to work overseeing the female workers while working, so that it produces a maximum production. This condition shows that those with dominant positions (the rulers) show their strength to other parties (female workers), and maintain as well as strengthen the emotional ties of subalterns (female workers) in order to obey the rules. Spivak reviews the subaltern from what elites do to women from perspectives of socio-cultural, religious and public policy. 
This study intends to examine and understand the female workers who work in the industry sector undergoing subalterns at work by using postcolonial feminist theory of subaltern concept which is developed by Gayatri Spivak. Spivak tries to explain the women's ideas and actions based on the experiences of third-world women, Spivak tries to discuss the subject of female subaltern groups in the third-world colonial period. Spivak stresses that female subaltern groups cannot speak out against colonial rule.Meanwhile, when discussing the subject of female subaltern, at PT Industri Karet Deli, they (female workers) experience oppressions in the workplace, but they are silent in accepting it. Spivak notes that "either as objects of colonialist historiography or as the subject of rebellion, gender ideological construct retains the male as dominant parties. If in the context of subaltern colonial formation there has no place to play a role in the economy and they cannot speak.

The study of this subaltern is important to perform, because it does not merely examine the female workers who experience the subaltern, in the domestic and public areas of the industrial sector, but this study describes the meaning of subaltern experienced by female workers viewed from the perspective of Gayatri Spivak postcolonial feminism. If the subaltern conception is interpreted as an attempt to present the coercion as a mechanism, the subalterns can occur in various forms of oppression. This mechanism runs smoothly so that the causes of the dominated ones are unconscious, obedient and accept it. This study also discusses the oppressions experienced by female workers due to patriarchal culture and gender imbalances and reveals, examines as well as understands the meaning of subaltern experienced by female workers in the industrial sector. The purpose of this research is: a) describing the subaltern experienced by the female workers of PT Industri Karet Deli due to patriarchal culture and gender imbalance. b) understanding the meaning of subaltern experienced by female laborers from Gayatri Spivak perspectives in PT Industri Karet Deli.

This study uses feminist ethnography method with qualitative approach. The feminist ethnographic method used in this study is to focus on the diverse situation of problematic women and the institutions that frame the situation, in which the researcher reveals and deconstructs the experience of female workers who experience oppression in their workplace due to patriarchy and inequality gender, besides that it enables the researcher to know exactly who suppressed the female workers when female workers experience oppression in their workplace and develop as well as confirm what identity and what process the oppression takes place (Reinhartz, 2005: 67).The research location is in Medan City with industrial object or factory that employs 68\% female. The data collection is conducted by observation, interview, and supported by documents. The research subject is female and male workers. This study explains that the domination relationship to the subordinate party in some former colonial societies about the issue of gender difference and the pressure of the ruler in the life of women. The relationship between female workers and the entrepreneur, or female workers with other workers, there are certainly some people who are entrusted by employers to oversee the female workers while working, so that it produces maximum production.

\section{METHODOLOGY}

This condition shows that those with dominant positions (the rulers) show their strength to other parties (female workers), and maintain as well as strengthen the emotional ties of subalterns (female workers) in order to obey the rules. The phenomenon of female's struggle against industrial entrepreneurs on the arbitrary acts to female factory workers is an empirical portrait of the discourse of subaltern group struggle introduced by Spivak, or "silent" group. In Indonesia there are many oppressed female workers cases conducted by the entrepreneur in the industrial sector that mostly committed violations of maternity rights, wages, recruitment systems, sexual harassment, working hours, dismissal after maternity leave to miscarriage at work. On the other hand, the increasing number of female workers in the industrial sector provides an opportunity for women to participate in the public sector with various reasons such as to improve the economic income of the family, or a change in the pattern of women's views if they work in public sector which is considered higher than domestic work, This situation is used by the company to recruit female as laborers in his company. Women who work in the industrial sector experience an increasingly more competitive economic subaltern, because of their low wages compared to male labor. This is due to the company imposes the patriarchal relations in the production process in the company.

\section{DISCUSSION}

The study of patriarchal culture originally was used to refer to a type of family controlled by men or a power relationship with what men posses women, a pattern of patriarchal cultural relationships that emerged in the society to differentiate between men and women in power relationship where the patriarchal system puts the dominated women and subordinated within the scope of patriarchal society by placing men as dominant in the family. This system is alive from the lower, middle and even up to the high class (Juliet, 2000: 54).The above occurs because of the belief that the woman's nature is weak and her position is under man, to serve and not as the head of the household. The difference between men and women is due to patriarchy that has resulted an imbalance in the form of subordination, domination, discrimination, marginalization, strerotype. The imbalance 
forms are the main source of exploitation on women. The patriarchy perspective exploration is always addressed to the women.

According to Juliet (2000: 87) patriarchal cultural factors that cause the occurrence of subaltern on women are as follows:

(i) the relationship of patriarchal in the family where a woman is controlled by her husband. The relationship of production patriarchal is one of two patriarchal structures that takes place at the economic level. Women are controlled by their husbands in marriage bonds and domestic relationships. Women as wives do such work for their husbands and in certain environments, without getting any wages from such work because it is the consequence of the marriage bond.

(ii) Patriarchal relationship in waged employment, means that women are kept away from waged employment. This condition causes a work devaluation of women and low wages for them. This has become a social fact with determinant effects, not only for women in the work environment, but also in other areas including domestic space as well as other aspects in gender relationship. The concrete aspect of patriarchal relationship is the division of work. The division of work has several forms either vertically or horizontally and between full-time and part-time.

In the level of vertical and horizontal hierarchy, for example, women are often categorized as 'less skilled' than men. The distinction between full-time and part-time work makes the difference in the number of legal protection given to female workers. The presence of female workers in the industrial sector makes clear the difference in wage conditions with male workers.

The work separation can differentiate wages received by women. The women's work is classified into what economists say the secondary labor market, with low wages, high job instability, and little benefit. Wage which becomes one of the essences of work agreement is important factor that determines the presence or absence of a working relationship. In addition, wage is also one of the controversial issues, since wage has always been the starting point of conflict between female workers and employers.

(iii) The patriarchal relationship in the state/company, state and company has a systematic bias against patriarchal interests as seen in its policies and actions. Its influence on gender relationship is not a consequence of being a capitalist state, but from the patriarchal origin of the state. Women are kept away from access to the state and power resources as part of the patriarchal system. The state patriarchal relationship to female workers in the industrial sector is the issuance of Law No.13 year 2003 about labor regulations. With the issuance of the law it is beneficial for the industrialists where the outsourcing system, subcontracting is a very powerful management strategy to gain maximum profit. The outsourcing mechanism has become a labor system that denies labor rights. The working contract system is getting widespread and almost all companies or industries currently have shorter contracts and outsourcing for some of their workforce, this is very detrimental to female and male workers.

The position of female workers is weakened by the implementation of contracted and outsourced labor systems in the companies. The companies employ female workers as contracted and outsourced workers who do not have the same normative rights as permanent workers. Due to the status of contracted workers, they are vulnerable to experience various rights violation issues, such as employment dismissal (PHK) unilaterally without apparent reason, low wages, unlimited hours, prohibition of freedom in association, uncomfortable working conditions and facilities, prohibition of miscarriage and pregnancy. Although it is the rights of female workers to get maternity leave, but their wages are cut and not paid during the leave because they are considered unproductive by the company.

(iv)Patriarchal relationship in sexual harassment is the male side which is very dominant in creating the female's identity into a second-class, so that men can act in their own way, thus, sexual harassment affects other aspects of gender relations. Sexual harassment is any unwelcome sexual act, request for sexual acts, oral or physical acts or sexual gestures, or any other sexual behaviors that make a person feels offended, embarrassed and/or intimidated. The sexual harassment toward the female workers is not separated from the value concept that sees a woman as a feminist who deserves to get the temptation. This does not occur toward the male workers who are considered to be the ones who perform the harassment and temptation, at work.

\section{CONCLUSION}

Female workers who work in the industrial sector are due to the family economic factors, although they still pursue the work. Besides there is no other choice, it is because of social-cultural factors that restrict their movements. For women who are not married, working is to help parents, while for those who have a family working is an important activity to meet the needs of everyday life. The influence of the patriarchal culture is the division of work by gender in which the public-sector patriarchal society is linked to male and the domestic or household sector is associated with female. In the system of industrial society and capitalist, everything is valued according to its exchange rate on the market, demand and the supply or becomes the commodities, including human (men and women). On the other hand, in pursuing the public sector by working in the Deli 
Rubber Industry provides the consequences for them. Besides getting wages, of course, they also have to bear the dual role (domestic and public) in everyday life. This situation creates problems in gender inequality, because men who are responsible to earn a living generally are not volunteered to help their wives do their housework. The patriarchal culture influences the people's mindset. The gender differences have created various inequities for women. The difference of men and women is due to patriarchy has turned out to create inequality in the form of subordination, oppression, discrimination, marginalization, stereotype, double burden. These inequality forms are the main source of women exploitation. In the perspective of patriarchy, exploration is always addressed to the women.

The subalterns that occur in female workers make the female workers to speak and to reject the treatment of gender inequality and the patriarchal culture conducted by the company, in the form of writing conveyed through the extension of representatives of Indonesian trade unions in PT Industri Karet Deli, the foreman, or included in the suggestion box. Besides that, a deep thought about the reality of marginalized female workers in which there are oppressions that involve the "insiders" are included new, although they are not really new.

The depth of Gayatri Spivak's study according to the researcher is inseparable from his background who involves across the boundaries of the study. Subaltern is just one of the many ideas he has developed and strived for. Those who are marginalized are not able to speak but not because they cannot but because too many people who speak on their behalf. The author believes in certain limits they can shout.

In spite of this figure of ours it is very worthy and liable for us to make her as reference and examples in some ways. The services she contributed cannot be counted in the progress of social science and the struggle to defend those who are marginalized.Spivak's thought gives the discourse that women experience oppression, even she criticizes the people who cannot speak is the silent people. She says when a person cannot speak it is categorized as a dead person. According to her the silence shows on oppression against all women in India. Spivak's postcolonial discourse to convey the silence is called the subaltern (Morton, 2008: 184).

\section{REFERENCES}

[1] Juliet Mitchell 2000. "Patriarchy and Matriarchy", Feminist Concepts Series, SNDT Bombay.Haryani, Sri.2002. Hubungan Industrial di Indonesia.Yogyakarta: UnitPenerbit dan Percetakan AMP YKPN

[2] Spivak, Gayatri Chakravorty.2010."Can the Subaltern Speak? Postkolonialitat und subaltern Artikulation

[3] Spivak, Gayatri Chakravorty.2008,"Can the Subaltern Speak?”. Dalam Bill

[4] Ashcroff, Gareth, dan HellenTiffin (eds). The Poscolonial studies Reader,

[5] Second Edition, Routledge: London

[6] Spivak, Gayatri Chakravorty.1987. "Speculations on Reading Marx:After Reading

[7] Derrida," in Derek Attridge et al (eds), Post-Structuralism and the

[8] Question of History, Cambridge: Cambridge University Press pp 30-62

[9] Spivak, Gayatri Chakravorty 1990. The Poscolonial Critic.Interviews, Strategis,

[10] Dialogis.Harasyim,Sarah (edit). Routledge. An Imprint of Routledge

[11] Cahpman and Hall, Inc : New York 